Acta medico-historica Rigensia (2019) XII: 92-122

doi:10.25143/amhr.2019.XII.04

Ineta Lip̌̌a

\title{
Categorized Soviet Citizens in the Context of the Policy of Fighting Venereal Disease in the Soviet Latvia from Khrushchev to Gorbachev (1955-1985) ${ }^{1}$
}

\begin{abstract}
In the Soviet period, the incidence of venereal diseases (VDs) ${ }^{2}$ was ideologically interpreted by authorities as a deficiency inherent in capitalist countries. It was stated that VDs would be eliminated in the Soviet Union at the earliest possible date. Compared to the independent Republic of Latvia (1918-1940), during the Soviet period, despite a larger population, the number of registered VDs infected patients was significantly lower. In such a historical context, a strange ideological obsession could be observed in the activities pursued by Soviet authorities when fighting VDs. The notion of the VDs as a remnant of the capitalist system determined the treatment of Soviet citizens infected by the VDs as marginalised populations. In order to achieve the goal of becoming a country where the VDs were eliminated, the Soviet Union practised a drastic dispensarisation system in the treatment of VDs, which was focused only on certain groups of the population that were identified in the documents of internal use for

1 The author's work on this article constitutes a part of the University of Latvia project No. ZD2015/AZ85.

2 The term "sexually transmitted disease" has now replaced "venereal disease". " "Venereal disease" was used from the eighteenth to the late twentieth centuries to refer mainly to syphilis and gonorrhea." See: Pamela Cox, "Compulsion, Voluntarism, and Venereal Disease: Governing Sexual Health in England after the Contagious Diseases Acts", Journal of British Studies 46, no. 1 (January 2007): 91-115.
\end{abstract}


the fight against VDs. Starting with the 1960s, the VDs fighting policy also included the fight against prostitution, euphemised as the fight against "frivolous women", by directing the control against the female gender. At the same time, the decisions at the highest level of the Soviet government, that were mostly marked by the "not to be published" stamp, formally corresponded to the ideas of gender equality and Soviet ideas of rule of law. In the context of the marginalised populations, authorities were of the opinion that it was justifiable to humiliate citizens, who would be forced to undergo unjustified medical examination, because the smallest proportion of marginalised populations, who were subjected to forced medical examination, turned out to be VDs positive. When assessing the extension of such practices to the wider population, it was recognised that this would not contribute to the strengthening of the Soviet rule of law. The purpose of the article is to reveal the development of the population categorisation practice in the context of the VDs fighting policy in the Latvian SSR.

Keywords: Fighting VDs, immoral and parasitic lifestyle, marginalised populations, prostitution, male homosexuals, the Soviet Union (SU), the Latvian SSR (LSSR).

In the 1950s the ideologues of the Soviet Union promoted the idea that socialist society does not have VDs and that VDs exist only as long as there are remnants of capitalism in the consciousness of certain individuals. ${ }^{3}$ Any success, including in the field of health, in the SU was seen as the consequences of the implementation of the decisions taken by the Communist Party of the SU (CPSU), articulated in the formula that, thanks to the measures adopted by the CPSU and the Soviet Government, as well as the assistance provided by the health care authorities, VDs morbidity began to decrease sharply from 1947. The success was explained by the claim that in the socialist society the social and economic circumstances that facilitate the incidence and spread of VDs have been eliminated. Similarly, in 1955 it was announced that "the decisions of the XIX Congress of the Communist Party of the Soviet Union in the field of health are a guarantee that venereal diseases will be eliminated." ${ }^{4}$ The Central

3 L. V. Belova-Rakhimova, V. I. Prokhorenkov and T. N. Guzei, "Puti razvitiia venerologii v Rossii i SSSR (1950-1959)”, Vestnik Dermatologii i Venerologii 2 (2015): 142.

4 Ibid. 
Committee (CC) of the CPSU and the Council of Ministers (CM) of the SU, in a resolution of 1960, ordered the Ministry of Health Care (MHC) to eliminate a number of infectious diseases, including syphilis, in the coming years. ${ }^{5}$ From the late 1950s, the VDs fighting policy was influenced by the ideology promoting Communist puritanism, as well as by the inclusion of the Moral Code of the Builder of Communism in the programme of the CPSU in 1961. ${ }^{6}$ Thus, the regulations of the VDs fighting measures were activated from above. The scheme was following - reacting to the statistics on the morbidity of VDs, first, a resolution (postanovlenie) of the CM and/or a decree (dekret) of the Presidium of Supreme Soviet (PSS) of the SU was issued in Moscow, then it was followed by a resolution of the CM and/or a decree of the PSS of the LSSR. The decrees of the CM on the fighting VDs were marked as "secret, not to be published". The abovementioned authorities issued such decisions every few years without significantly changing the titles of the decisions. It was a practice used in the SU - to address specific social challenges when issuing special decisions. Whereas the MHC of the LSSR reported annually to the MHC of the SU, in terms of the achieved results, implementing the latest decision of the CM or the decree of the PSS or the order (prikaz) of the MHC of the SU on fighting VDs in the previous year.

The policy documents on fighting VDs can be divided in two levels. In the early 1960s a different language was established in the documents of two levels - the documents of the CC of the CPSU/CPSL and the CM of the SU/LSSR as the documents of the highest level and secondary level, namely, the documents of internal use in ministries/authorities. The language of the highest-level documents had a general form of expression, while in the documents of internal use in ministries/authorities a more direct language was used. In the context of the VDs fighting, Soviet citizens were categorised in the documents of the secondary level. In the VDs fighting policy documents of the highest level a social group

5 State Archive of Latvia at the National Archives of Latvia (Latvijas Nacionālais arhīvs Latvijas Valsts arhīvs, hereinafter LNA LVA), 270-3-344, 173-177; here: 176. Resolution of the CC of the CPSU and the CM of the SU No. 58, 14 January 1960. "On Measures to Further Improve Medical Services and Health Care of the Population of the SU".

6 Deborah A. Field, "Irreconcilable Differences: Divorce and Conceptions of Private Life in the Khrushchev Era," The Russian Review 57, no. 4 (1998): 600-605. 
under the label "prostitutes" was never mentioned, whereas in the documents of secondary level the concept of a prostitute was used at least from the mid-1960s.

In the 1920s-1930s, approximately 10 thousand people infected with VDs were registered annually, ${ }^{7}$ while in Soviet Latvia, despite intensive migration from other republics of the Soviet Union, approximately one thousand Soviet citizens infected with VDs, were registered in 1959, while the index was the highest in 1973 - around six thousand became infected. The statement that the VDs exist as long as the remnants of capitalism have not been eliminated in people's consciousness has ideologically distinguished between the people who have contracted VDs and the rest of the Soviet citizens, where the VDs patients were regarded as somebody who discredited the socialist regime and, thus, were deserving of being held in low regard. The new aspect was only the ideological component that was added to the negative attitude towards the individuals, who had contracted VDs, because before World War II attitude was similarly negative in Latvia. It was determined by historical circumstances, whereby the VDs policy and practice in the $19^{\text {th }}$ century, when Latvia was incorporated into the Russian Empire, as well as in the period of independent Latvia (1918-1940) was reduced to the fighting of prostitution. ${ }^{8}$ After World War II in the occupied Soviet Latvia, prostitutes were not defined as a special risk group among the VDs patients in the official VDs fighting policy in the 1940s. Soviet ideologues argued that prostitution was created by the capitalist system, so the economic basis of prostitution had been lost in the socialist SU and it did not exist. Due to this ideological framework, it was not possible to base the Soviet VDs fighting policy on the pre-war notions. Therefore, using the terminology of the "antisocial-parasitic

7 Ineta Lipša. Seksualitāte un sociālā kontrole Latvijāa, 1914-1939 [Sexuality and Social Control in Latvia, 1914-1939]. Rīga: Zinātne, 2014, 436.

8 Vita Zelče. Nezināmā. Latvijas sievietes 19. gadsimta otrajā pusē [The Unknown. Latvia's Women in the Second Half of the 19th Century]. Rīga: Latvijas Arhīvistu biedrība, 2002, 197-223; Vita Zelče, Vineta Sprugaine. Marginālās jeb 1376. fonds [The Marginal Ones, or Fund No. 1376]. Rīga: Latvijas Valsts vēstures arhīvs, 2005, 79-90; Ineta Lipša. Seksualitāte un sociālā kontrole Latvijā, 1914-1939 [Sexuality and Social Control in Latvia, 1914-1939]. Rīga: Zinātne, 2014, 435-455; Siobhán Hearne. To Denounce or Defend? Public Participation in the Policing of Prostitution in Late Imperial Russia. Kritika: Explorations in Russian and Eurasian History 19, no. 4 (Fall 2018), 717-744, https://doi.org/10.1353/kri.2018.0042. 
lifestyle" fighting, prostitution as one of the subgroups was euphemised under the label "frivolous women" (zhenshchiny legkogo povedeniia). ${ }^{9}$ However, the fighting mechanism could not be directed at the selling of sex; instead, it could be directed at those individuals, who did not have paid employment and/or lived without a declared address. If a seller of sex worked in official workplace and had a shelter, the law was not violated in the event of selling sex.

In the 1950s the VDs fighting policy and practice included other marginalised groups of society. First, persons leading antisocial and parasitic lifestyle - this was a category of citizens that was established in the SU already before World War II. This group of citizens was set apart already by the 1951 and 1957 and 1961 Decrees. ${ }^{10}$ By the early 1950s also in Germany in the zones occupied by allies "persons who transgressed the legal boundaries of social life and public health" were stigmatised/categorised as 'antisocial' and were confined into correctional institutions. ${ }^{11}$ Thus, the practice of pre-war Germany was continued. Historian Markus Wahl states that "from the post-war East German perspective, the term 'antisocial' describes the extreme forms of deviance that were pathologized and stigmatized by authorities and society". ${ }^{12}$ They were viewed also as supposedly 'promiscuous persons'. Since the early 1960s in the LSSR, the social control of the group labelled as "persons leading antisocial and parasitic lifestyle" was enforced with medical control, and in the context of VDs fighting policy, the word "antisocial" was replaced with the word "immoral" in the group's label. Within the group, the category of "frivolous women" was set apart.

${ }^{9}$ On the prostitution fighting policy in the LSSR: Ineta Lipša, "Inbetween Frivolous Women and Prostitutes: Legal Framework and Reality of Prostitution in the Soviet Latvia in the Context of Soviet Family Politics, the 1950s-1980s", Nordost-Archiv. Zeitschrift für Regionalgeschichte. Neue Folge (forthcoming 2020).

10 The Decree of the PSS of the LSSR, 18 August 1961 "On the Intensification of the Fight against the Persons, Who Avoid Socially Useful Work and Lead an Antisocial Parasitic Lifestyle". It was elaborated according to an analogue decree issued 4 May 1961 by the PSS of the RSFSR. See: Ibid.

11 Markus Wahl, "The Workhouse Dresden-Leuben after 1945: A Mircostudy of Local Continuities in Postwar East Germany", Journal of Contemporary History (2018): 1-25. https://doi.org/10.1177/0022009418771747.

12 Ibid., 4. 
In order to analyse how Soviet citizens were categorised in the context of the VDs fighting policy in Soviet Latvia from 1955 to 1985, first, the system of Soviet institutions that implemented the fighting VDs will be characterised - the system of dispensarisation (dispanserizatsiya), which after World War II was introduced in Latvia by the authorities of Soviet occupation for the purposes of VDs fighting corresponding to the practice that already existed in the SU. Further on, it will be analysed how in the 1950s special risk groups (persons with antisocial and parasitic lifestyle, male homosexuals and prostitutes) were introduced in the secondary level documents of the VDs fighting practice and how the list of target groups was detailed and amended. Analysing the most important VDs fighting policy documents - the 1964 and 1971 instructions, it will be investigated how, as a result of inter-departmental discussions between several authorities, the VDs fighting practice from gender neutral became gender (female) specific, and how the practice was institutionalised using a special operative militsiya group, maintaining a special filing system of prostitutes, male homosexuals and keepers of dens (pritony) (as allegedly VDs infected persons) simultaneously by law enforcement and medical authorities. As regards the development of VDs fighting practice in the 1970s-1980s, it will be argued that in this period the focus was narrowed down to the individuals with an immoral-parasitic lifestyle, establishing a special regime hospital in 1973 for the coercive treatment of seven subgroups of the respective target group (alcoholics, idlers (tuneiadtsy), male homosexuals, "frivolous women", pimps, occupants of dens, as well as disseminators of VDs as a separate subgroup). At the same time, law enforcement authorities tried to extend the targeted range of citizens, focusing on the prevention of promiscuous behaviour and regulation of sexual behaviour in the most extensive masses of citizens through the VDs prevention, popularising sexual knowledge not only in press publications since the 1960s, but also since the $1970 \mathrm{~s}$ - on the radio and TV discourse.

\section{Implementation of the Dispensarisation System}

In the 1940s after the occupation of Latvia, the fighting of VDs was the responsibility of the MHC. The MIA was involved in the VDs fighting since the early 1960s. By 1951, the SU had managed to reduce the incidence 
of the active forms of syphilis by 32.8 times, using a dispensarisation system. ${ }^{13}$ After World War II, the new type of medical institutions - dispensaries - were also introduced in the occupied Latvia. These were dermatological-venereological dispensaries in urban areas, whereas in the rural areas these were dermatological-venereological consulting rooms that were open at the regional hospitals and were under the control of dispensaries at the republican or city level. The dispensaries were located in Riga and the biggest cities - Rēzekne, Daugavpils, Liepāja, Ventspils, for some time in Jelgava, too. There were two dispensaries in Riga: the city dispensary ${ }^{14}$ and the republican dispensary ${ }^{15}$. In-patient hospital (statsionar) with men and women's units was only available at the city dispensary. In the mid1950s the SU health care leaders, taking into account the positive indicators in the VDs fighting statistics, considerably reduced the number of dermatological-venereological institutions in the time period from 1955 to 1962. ${ }^{16}$ In 1956 the LSSR republican dermatological-venereological dispensary was closed down (re-opened again in 1973).

Dzidra Branta, dermatovenereologist, who had worked at the dermatological-venereological dispensary in Riga since the early 1950s, has stated in her memoirs that "in social terms the system was effective, but it was cruel towards the individual who had entered the system". She writes that Professor Anatoly Kartamishev, ${ }^{17}$ who was the Head of the Dermatological and Venereal Disease Department at the Central Institute of Physician Qualification (1953-1970), often came to Riga from Moscow to provide consultations at the dermatological-venereological dispensary of Riga. According to Branta, once he said that the system of

13 A. A. Kubanova, A. A. Martynov and A. V. Vlasova, "Vekovoi opyt otechestvennoi dermatovenerologii. Etapy razvitiia kozhno-venerelogocheskoi pomoshchi naseleniiu (chast' II)", Vestnik Dermatologii i Venerologii 94, no. 1 (2018):14-26; here: 16. DOI: 10.25208/0042-4609-2018-94-1-14-26.

14 The Riga city dispensary was located in the territory of Riga 1st Joint Clinical Hospital at Bruninieku Street 5.

15 The Republican dispensary was located ar Skolas Street 28, Riga in the building of the MHC of the LSSR.

16 A. A. Kubanova, A. A. Martynov and A. V. Vlasova, "Vekovoi opyt otechestvennoi dermatovenerologii", 18.

17 Anatolii Kartamishev (1897-1973), dermatovenerologist, professor, head of the Department of Skin and Venereal Diseases (1953-1970) at Moscow Central Institute for Qualification of Physicians (Tsentral'nyi institut usovershenstvivaniia vrachei). 
dispensaries was a real "mincer", namely, that the welfare of society was established at the expense of individual rights. Branta describes the system as follows:

"All patients to be hospitalised at dispensaries were registered in a special outpatient filing forms (outpatient medical case histories) and a sophisticated reporting form. These last were sent to the special services (disinfection and statistics institutions). In the dispensarisation system the key goal was to discover and eliminate the source of infection. In fact, it meant that information had to be obtained from the patient to find out the focus of infection the individual, from whom he had contracted the disease, as well as contact persons, namely, those individuals, whom the patient could have infected. All these individuals were identified, examined or eventually they had to undergo a preventive treatment course. Examination and treatment were compulsory; it was stipulated by law.

The patient had no choice. Special nurses and physicians' assistants were engaged in identifying the focus of infection and contact persons. The physicians - the health visitors' staff - were also engaged. If the patient avoided the examination or treatment, militsiya was involved and the patient was taken to the dispensary by force. There were also threats to make the information about the infection public at the workplace or family. Treatment took place at the in-patient hospital. The windows at the wards, where venereal disease patients were treated, had iron-bars." 18

The physicians were verbally abused by the administration of dispensaries and the representatives of the $\mathrm{MHC}$, if they failed to find out the foci of infection and contact persons. Branta writes that sometimes she felt like a human torturer, when she had to find out the contact persons:

"In the late 1950s, when syphilis was spreading among homosexual men, I frequently experienced unpleasant moments, when I tried to identify the focus of infection and contact persons of a homosexual patient. Unthinkable stories were provided, which gave rise not to compassion and pity, but to laughter and fun. Sometimes there were tears. I remember many occasions when we both cried: me because of anger, the patient - because of pity. Often, I felt compassionate, when I felt not as a physician, but as a human torturer." 19

18 Dzidra Branta, Atmingas un apcere [Memories and reflection] (Rīga: Nacionālais Apgāds, 2007), 87, 89.

19 Ibid., 88. 
Identification of the focus of infection was the core axis around which the VDs dispensarisation policy revolved. Therefore, in the course of treatment individuals had to name all their sexual partners. For male homosexuals, it meant not only confessing to the crime of sodomy, but also providing the names of other "criminal suspects" because male sodomy was criminal crime in the SU. ${ }^{20}$

\section{Beginning of the Formulation of Marginalised Populations}

When analysing the morbidity rate of syphilis in the LSSR from 1960 to 1965 , the MHC concluded that the prevalence of women is insignificant in the latent forms of syphilis, whereas among the infected individuals with active forms "men prevail, mostly because of homosexuals". ${ }^{21}$ Thus, male homosexuals attracted the attention of $\mathrm{HC}$ authorities, since they were defined as the large source of syphilis dissemination in its active form among men. As a result, the Soviet Latvian VDs service faced increasing recognition of the existence of male homosexuality, which can be compared to Great Britain during the $1950 \mathrm{~s},{ }^{22}$ where after prolonged parliamentary and public debate, the Wolfenden Report led to legislation

20 There was no any period of decriminalization of male sodomy in Latvia as it was in Soviet Russia from 1917 to 1934. By August 1, 1933 the punishment for male sodomy in the Republic of Latvia was imprisonment for a period of no less than three months, afterwards - imprisonment without a specific duration, which, in practice, usually meant imprisonment for up to three months. In 1940, the Soviet occupation introduced more repressive policies. Until 1961, in accordance with Article 154a of the Criminal Code of the Russian Soviet Federative Socialist Republic, the punishment for the same "offence" was imprisonment for a period of three to five years. The Latvian SSR Criminal Code came into force on April 1, 1961. In a way it reduced the possible punishment because Article 124 Paragraph 1 did not impose a minimum sentence, but it did determine that a man guilty of male same-sex intercourse should be sentenced to imprisonment for up to five years. The Article was abolished on 1 March, 1992 in the independent Republic of Latvia. See: Ineta Lipša, LGBTI People in Latvia: a History of the Past 100 Years (Rīga: LGBT un viñu draugu apvienība "Mozaīka", 2018), 17, 59, 88.

${ }^{21}$ LNA LVA, 1022-7-427, 2-96; here: 27. Conjuncture Review of the Operation of Skin Venerological Institutions of the LSSR in 1965, 18 June 1966.

22 David Evans, "Sexually Transmitted Disease Policy in the English National Health Service, 1948-2000. Continuity and social change", in Sex, Sin and Suffering. Venereal Disease and European Society since 1870, Routledge Studies in the Social History of Medicine, ed. Roger Davidson and Lesley Hall (London \& New York: Routledge, 2001), 245. 
partially decriminalising homosexual activity in 1967. Meanwhile, in the LSSR the topic was not discussed due to a situation where public debate in the Soviet system was not possible.

In the late 1950s the authorities of HC added the group of homosexual men to the risk groups in the documents of secondary level in the VDs fighting policy (male homosexuals were set apart as an individual group in statistics of syphilis morbidity in 1956). In the HC statistics of the LSSR, the total number of registered individuals who had contracted the active forms of syphilis in 1956-1965 was indicated specifying the statistics with the following note "including among homosexuals" (out of the 194 registered infected male individuals 83 , or $43 \%$, were homosexuals). ${ }^{23}$

Near the same time male homosexuals were identified as a target group in the complex plans of the HC institutions to fight VDs. The ministry prepared such plans every year; however, the 1961-1962 plans are the first where a certain social group was identified as dangerous, namely, women who implement "immoral way of life in terms of sex life and who are malevolent sources of infection". ${ }^{24}$ The 1964 plan added the group of male homosexuals, stipulating that it is necessary to "establish a regular exchange of information with the militsiya and public prosecution structures in order to examine the homosexuals who have contracted venereal diseases". ${ }^{25}$

In 1962, the subcategory of the immoral-parasitic lifestyle group was included in the VDs treatment practice, because another unit was opened at the in-patient hospital of the dermatological-venereological dispensary of the city of Riga - the so-called regime in-patient hospital, which was intended for persons leading an "immoral-parasitic lifestyle". ${ }^{26}$ Previously, Soviet citizens infected with VDs were treated together. The regime inpatient hospital was guarded by the militsiya guards. When the external

${ }^{23}$ LNA LVA, 1022-7-427, 28.; LNA LVA, 1022-7-347, 1-52; here: 24. Conjuncture Review of the Operation of Skin Venerological Institutions of the LSSR in 1961, 5 June 1962.

${ }^{24}$ LNA LVA, 1022-7-337, 3-17; here: 6. The 1961 Comprehensive Plan of the Ministry of Health Care of the LSSR for Fighting Skin and Venereal Diseases and Leprosy, 23 March 1961.

25 LNA LVA, 1022-7-403, 1-12; here: 3. The 1964 Comprehensive Plan of the Ministry of Health Care of the LSSR for Fighting Skin, Venereal Diseases and Leprosy.

${ }^{26}$ LNA LVA, 1022-7-456, 20-24; here: 20. Information (spravka) on the State of the Incidence of Syphilis and Gonorrhea in the LSSR and Measures to Strengthen the Fight against Them, 5 March 1971. 
24/7 militsiya security was removed from the regime in-patient hospital for three years starting from 1968, the MHC demanded to restore it, because without the militsiya guards the patients engaged in fights and consumed alcohol, used force against the medical staff, ignored the requirements, behaved like hooligans and cursed using uncensored language. The patients sawed the iron-bars of the windows and fled the treatment institution. ${ }^{27}$ Physician Dzirda Branta also recalls the behaviour of this group. The funny event with the chief physician of the dispensary took place in the 1950s1960 s, when during the night duty the prostitutes, who were treated in the women's unit, started a riot.

"As far as I remember, the frustration was caused by the poorquality catering. The patients had learned that the chief physician was on the night duty. They attacked Cipkins and tried to 'rape' him. Cipkins was saved by the militsiya officer, who was on duty and who was informed by the dermatological patients. The staff of dispensary laughed furtively about this event for a long time." 28

In general, in the early 1960s as a result of the ideological pressure (to eliminate syphilis in the SU), healthcare employees were mobilised to incorporate in the VDs fighting policy documents the socially marginal groups, which had been identified previously for other purposes, into the Soviet population (individuals who avoid socially useful work) and included homosexuals.

\section{The High-level Documents: Discussing the 1964 Draft Resolution}

By 1960, syphilis and gonorrhoea morbidity decreased in the LSSR; however, already in 1962, the LSSR became part of the group of those regions (numerous cities of the Russian Socialist Federative Soviet Republics (RSFSR), as well as Estonian SSR, Lithuanian SSR and Moldavian SSR), where gonorrhoea morbidity sharply increased. ${ }^{29}$ (In 1959 there were

27 LNA LVA, 1022-7-456, 20-24; here: 23, 24. Information (spravka) on the State of the Incidence of Syphilis and Gonorrhea in the LSSR and Measures to Strengthen the Fight against Them, 5 March 1971.

28 Dzidra Branta, Atminas un apcere, 99.

29 Prikaz Ministerstva zdravookhraneniia SSSR No. 86, 27.02.1963. O meropriiatiiakh po likvidatsii zabolevaemosti sifilisom i rezkomu snizheniiu gonorei v SSR. http:// rudoctor.net/medicine/bz-uw/med-vmpac/index.htm [sk. 21.10.2016.]. 
65 incidence cases of syphilis and 984 incidence cases of gonorrhoea registered, but in 1963 - 105 and 3350 respectively. ${ }^{30}$ )

In the 1960s in the LSSR, the highest morbidity level was registered in 1964. ${ }^{31}$ The MHC of the LSSR was of the opinion that the reason was the comparatively quickly increased "clandestine prostitution", which was facilitated by the "withdrawal of the passport regime", which for the persons with "immoral-parasitic lifestyle", provided an opportunity to live without a declared address and to lead the antisocial lifestyle without hindrance. ${ }^{32}$

The 1963 Order of the MHC of the SU on "Measures to be Taken to Eliminate Syphilis Morbidity and to Decrease Gonorrhoea Morbidity" stipulated the cooperation of the Ministries of $\mathrm{HC}$ and IA, the Prosecution Office, as well as other offices (resory) in order to bring down new cases of VDs. Additionally, protection measures were introduced that were supposed to include society through the action of collective organisations, such as Comrades' courts, trade unions, volunteer militias, the Komsomol, the Communist party etc. The Decree ordered the use of options provided in the 1961 Decree for fighting "antisocial and parasitic lifestyle" in fighting VDs. The 1963 Order required the MHC of the LSSR to draft a VDs fighting plan attracting the representatives of other authorities. The MHC of the LSSR in the 1964 plan named 4 target groups: persons with "immoral lifestyle in terms of sex life", persons, who avoided socially useful work and spread VDs, the VDs infected male homosexuals, as well as addresses of the apartments, which were defined as "lechery dens". ${ }^{33}$ Thus the 1964 Resolution of the CM of the LSSR was pushed by the 1963 Order of the MHC of the SU. ${ }^{34}$ The republican MHC informed the CM of the LSSR that the measures to fight VDs had exceeded the framework of the medical authorities and stated that there had to be not only therapeutic, but also educational and compulsory activities. ${ }^{35}$

30 LNA LVA, 938-6-325, 2-4; here: 2. Draft Decree of the CM of the LSSR on Measures to Fight VDs, elaborated by the LAC at the CM of the LSSR, 8 April 1964.

31 LNA LVA, 1022-7-456, 20.

32 Ibid.

33 LNA LVA, 1022-7-403, 3.

34 LNA LVA, 270-3-2009, 109-110. Resolution of the CM of the LSSR No. 304, 26 May 1964 “On Measures to Fight Venereal Diseases”. Not to be published.

35 LNA LVA, 270-3-2009, 118-121; here: 118. The Letter of the MHC of the LSSR to the CC of CPL and the CM of the LSSR, 19 February 1964. 
The 1964 Draft Resolution was discussed by the MHC, MIA and the Legal Affairs Commission (LAC) at the CM of the LSSR. The LAC recommended targeting those individuals as well, who according to the verdict of law enforcement authorities led an immoral-parasitic lifestyle. ${ }^{36}$ Whereas the Minister of the MHC Vilhelms Kaneps ${ }^{37}$ had intended to cover a wider range of population, indicating certain locations in the social geography of Riga. Such an approach was not a new one. Already in 1949, the MHC, referring to the statistics of the first six months of 1949, marked certain locations in the social space of Riga, whose visitors should be medically controlled. 870 of the registered 982 infected individuals were of the opinion that they had contracted the infection - on street (17.4\%) and in dance parties (17.4\%), at the acquaintances' (15.5\%), in the park $(14.2 \%)$, in the family evening (11\%), at the partner's home (9.4\%), at their own home (8\%), in transport during business trip (7 \%). ${ }^{38}$ This data was not used in the VDs fighting policy. However, when discussing the 1964 Draft Resolution, the Minister of the MHC Vilhelms Kaneps drew attention to the social geography of Riga. He argued that the spread of VDs was affected by the sales of alcohol in restaurants. The Minister pointed out the fact that $83 \%$ of the infected people had contracted the infection from random individuals when they were under the influence of alcohol. He claimed that many employees of hotels, restaurants and taxis were engaged in pandering to bring the respective individuals together with the "women of immoral behaviour". ${ }^{9}$ The CM of the LSSR rejected the following proposals by the Minister: limiting alcohol sales in restaurants, asking the trust management of hotels to ensure that the rooms were not used for "lecherous lifestyle", asking the Ministry of Road Transport and Highways to prevent a situation, when the taxi drivers were engaged in pandering, asking the Republican Council of Resort Administration of Latvia to provide systematic "anti-venereal propaganda" among holidaymakers. However, the MIA named three citizen groups - "frivolous women", keepers of lechery dens and pimps. ${ }^{40}$ Thus, the MIA essentially identified

36 LNA LVA, 938-6-325, 3.

37 Vilhelms Kaneps (1923-1993), the first deputy of the Minister of HC of the LSSR (1959-1962), minister of HC of the LSSR (1962-1989).

38 LNA LVA, 1022-1a-34, 29.

39 LNA LVA, 270-3-2009, 118-121.

40 LNA LVA, 270-3-2009, 122-123. Proposals of the Ministry of Public Order of the LSSR, March 1964. 
the VDs fighting policy with the prostitution fighting policy, without using the term of prostitution in the definition, whereas the MHC proposals were not gender specific. Still, in 1965 the MHC tried to prove that the VDs infected or "individuals, who lead immoral lifestyle, usually are inveterate drunkards (zlostnye pianitsy)"; therefore, the 1964 Decree of the PSS of the LSSR on enforced treatment of inveterate drunkards (alcoholics) and rehabilitation in medical-labour re-educational institution (lechebno trudovoi profilaktorii) should be applied. ${ }^{41}$ However, the LAC at the CM of the LSSR rejected this idea.

Medical employees based on the existing (unofficial/patriarchal) ideas about family values, which prohibited a woman (unlike a man) to use sexuality outside the marriage, and which punished the women for arbitrary use of sexuality, while encouraged the men. The VDs fighting practice from the 1960s was especially focused on the women whose behaviour was viewed by law enforcement authorities as frivolous, without taking into account their male partners. At the same time, in the Soviet official discourse it was stated that the socialist society, unlike the capitalist society, is characterised by the gender equality principle in all policies.

\section{The Secondary Level: Instructions and Filing Systems}

The highest-level documentation had to correspond to the values declared in the SU official discourse, for example, gender equality; therefore, in the 1964 resolution the citizen groups were not mentioned. However, in the 1964 and 1971 instructions on the arrangements for coerced medical examination of individuals, who are the sources of the VDs spreading, the broad categories of citizen are named. Whereas in the internal documentation of the MHC and MIA in the 1950s-1960s - mostly in the VDs fighting plans, reports and proposals on draft resolutions of the CM of the LSSR - the citizen groups have been named in detail.

The VDs fighting policy in the Soviet Union was not unified. For example, in the regulations of the RSFSR and Estonian SSR there was a legal norm stipulating coerced examination and treatment of the individuals who have contracted VDs, whereas in the regulations of Latvian SSR such norms were not introduced up to 1964 . Responding to the 1963 Order of the MHC

41 LNA LVA, 938-6-430, 55-57; here: 56. The Letter of the LAC at the CM of the LSSR to the CM of the LSSR, 7 July 1965. 
of the SU, in 1964 the MHC of the LSSR asked the CM of the LSSR to pass a resolution to provide it with the rights for coercive, medical examination and treatment of supposedly infected people, taking the 1946 Resolution of the CM of the Estonian SSR ${ }^{42}$ and the 1927 Resolution of the Council of Peoples' Commissars of the RSFSR ${ }^{43}$ as an example. ${ }^{44}$ In 1964, the MIA of the LSSR together with the MHC elaborated and adopted the instruction on the procedure, in which individuals who were sources of VDs dissemination had to be coercively examined and treated.

In the 1964 instruction four target groups were identified. It did not have gendered groups - neither male homosexuals (MHC), nor "frivolous women" (MIA), but individuals: who had contracted VDs, who avoided the treatment, as well as unquestionable and probable sources of infection, and the contact persons of the individuals who have contracted VDs, who avoid medical examination and about whom the medical authorities have facts about their potential infection with VDs. The VDs treatment system was harsh in a psychological sense too. The instruction stipulated that in terms of the people, who have contracted VDs due to casual affairs (sluchainye polovye sviazi), the $\mathrm{CP}$, the Young Communist League and the Trade Union organisations must be informed in the training and work places, but on certain occasions - the Party and Soviet authorities at a city (regional) level.

The formulation "individuals, who engage in sexual intercourse with the aim to get material benefit" latently pointed to the prostitutes without actually using the term itself. Furthermore, the formulation of the group including individuals, who "lead disorderly sexual lives" (vedushchie besporiadochnuiu polovuiu zhizn') ${ }^{45}$ was extremely vague and I have not succeeded in finding documents, where the meaning of the formulation

${ }^{42}$ LNA-LVA, 270-3-2009, 129-130. Resolution of the CM of the Estonian SSR, No. 364, 10 May 1946. On the Measures to Fight VDs; Ibid., 131-133. Instructions on Compulsory Medical Examination and Treatment of VDs Infected Patients, 10 May 1946.

43 LNA-LVA, 270-3-2009, 136-137. Resolution of the All-Russian Central Executive Committee (Vserossiysky Centralny Ispolnitelny Komitet, VTsIK) and the Council of People's Commissars (Soviet narodnykh kommissarov, SNK) of the RSFSR, 24 January 1927 "On the Measures to Fight VDs"; Ibid., 139-140. Instructions on the Application of the Resolution of VTsIK and SNK of the RSFSR, 24 January 1927.

44 LNA-LVA, 270-3-2009, 121.

${ }^{45}$ LNA LVA, 938-6-430, 64-65; here: 64. Instructions on the Application of the Resolution of the CM of the LSSR No. 304, 26 May 1964. "On Measures to Fight VDs", 6 August 1964. 
"disorderly sexual life" would be explained. Consequently, I have not succeeded in confirming or rejecting the hypothesis that this norm could have been intended to provide an opportunity to medically control the buyers of the sex services.

In the time period up to 1971, when a new instruction was adopted, medical authorities had formulated their intentions more accurately. In the 1965 report, the MHC identified the female group of "persons, who lead disorderly sexual lives" as the most important target group. The author of the report concluded that the coercive examination of the "women, who lead disorderly sexual lives", brought by the militsiya to hospital, "is justifiable and efficient tool in fighting the decrease of the gonorrhoea infection". ${ }^{46} \mathrm{He}$ connected the respective women with the citizen category - individuals with immoral, parasitic lifestyle, who mostly do not have a declared address or do not live in the declared address. He argued that to ensure the surveillance of this category cooperation with militsiya is very important. He based his argument on the data - in order to find one case of gonorrhoea, 850 women must be examined in compulsory medical examination, in the obstetrician-gynaecological institutions - 105 women, but among those women, who are brought by militsiya - only 6 women. Such an attitude was not something the SU characteristic. In Scotland the system also was focused on females ("habitual prostitutes"), who were being traced and persuaded to follow a treatment plan despite the fact that attempts to introduce a bill to provide for coercive examination and treatment of individuals suspected of suffering from VDs failed in Scotland in 1968.47

In 1965 the MHC recommended to subject the individuals (the gender was not indicated), who behaved immorally in public space (in the evenings, on the streets, etc.), to medical examination. ${ }^{48}$ Most likely, the recommendation was aimed at a wider audience of the population, because the law enforcement authorities dealt with the "frivolous women" without any ceremonies. Militsiya officers, engaging members of voluntary

46 LNA LVA, 1022-7-427, 62.

47 Roger Davidson, “The Price of the Permissive Society'. The epidemiology and control of VD and VDs in late-twentieth-century Scotland" in Sex, Sin and Suffering. Venereal Disease and European Society since 1870, Routledge Studies in the Social History of Medicine, ed. Roger Davidson and Lesley Hall (London \& New York: Routledge, 2001), 225.

48 LNA LVA, 938-6-430, 56. 
people's druzhina, unofficial militsiya employees (vneshtatnye sotrudniki militsii), as well as the operative units of the Communist Youth, had to raid the locations, where the "frivolous women" could gather (near the sea ports, railway stations, hotels, restaurants, parks and other recreational places of proletariat), in order "to take these women out and carry out preventive discussions with them" (po iz'iatiiu etikh zhenshchin s posleduiushchim profilaktirovaniem). Besides, the law enforcement authorities could send to medical examination those citizens, whom these authorities regarded as people with immoral and parasitic lifestyle.

The LAC, which evaluated the submitted legislative proposals, recommended not to accept the MHC proposal, explaining that so broad rights, essentially out of control, to subject individuals to the sexual health examination will not contribute to strengthening of the Soviet law and will offend those citizens, who will be unduly examined.

The 1964 Resolution entitled the Ministry of the IA to cooperate with the authorities of $\mathrm{HC}$ regarding the identification and transfer to coercive medical examination of the individuals, for whom it was justified to assume that they are infected with the VDs. ${ }^{49}$ The LAC found that individuals with parasitic lifestyle can be subjected to coercive medical examination. ${ }^{50}$ The VDs policy of the LSSR can be characterised by a contact tracing system launched by the governmental institutions through coercive medical examinations of marginalised populations, which was supplemented by the filing system of law enforcement and medical agencies. Such policy was in stark contrast with that of Great Britain where, as historian David Evans has argued, "from the late 1940s, the key VDs control mechanism promoted by the Ministry was the tracing of sexual contacts through the voluntary cooperation of patients, supplemented by professional contact tracers" and "the fundamental principles of policy were open access, treatment free at the point of service, confidentiality and non-coercion". ${ }^{51}$

I already mentioned that several proposals submitted by the Minister of the MHC Vilhelms Kaneps, including the limiting of alcohol sales in restaurants, were rejected in the debates on the draft decree; however,

\footnotetext{
49 LNA LVA, 270-3-2009, 109.

50 LNA LVA, 938-6-430, 56.

51 David Evans, "Sexually Transmitted Disease Policy in the English National Health Service, 1948-2000”, 240, 249.
} 
his proposal to establish an operative militsiya group for VDs fighting in the militsiya of Riga became the cornerstone of the VDs fighting practice. It was intended neither by the 1964 resolution, nor by the instruction; however, in 1965 law enforcement authorities institutionalised the fighting of VDs by set up a two-member operative militsiya group at the Criminal Investigation Department of the Administration of IA of the Riga Executive Committee (EC). ${ }^{52}$ One employee of the operative group registered data on women, who were claimed to be leading an immoral lifestyle, whereas the other employee gathered information on male homosexuals. The group closely collaborated with the Riga City Dispensary. Both, law enforcement and medical authorities established and maintained the respective filing systems (kartoteki). In 1965 all male homosexuals known to the Administration of IA of Riga EC had been medically examined, in order to find out individuals who had contracted syphilis. The very possibility that one could be forced to tolerate medical manipulations could be perceived as humiliation. Besides, most of the detained individuals (not only male homosexuals) turned out to be not infectious. For example, in 1968, out of the men who were taken for medical examinations under constraint only $5 \%$ turned out VDs positive, in 1969 it was $28 \%$, in 1970 it was $34 \% .53$

In the 1969 filing system of Riga militsiya there were data on 1639 women, "who were engaged in prostitution", on 481 male homosexuals and 89 apartments, "where men and women, who were engaged in alcohol consumption, lechery and brawls, systematically gathered". ${ }^{54}$ Overall the authorities were not interested in the fact that most of the male homosexuals and women, who were subjected to forced medical examination, were not infected. Apparently, the authorities were of the opinion that offense caused to these categorised citizens would not give rise to any problems.

Despite the fact that the VDs fighting policy was regulated by the previously mentioned CM of the LSSR resolution and instruction, in 1966 authorities started to work on the PSS of the LSSR draft order on the coercive treatment and re-education by labour of the VDs infected persons

52 LNA LVA, 1022-7-427, 62.

53 Their respective numbers were: 73 (4 persons were infected) - in 1968, 132 (37) - in 1969 and 112 (38) - in 1970. See: LNA LVA, 270-3-4939, 145. Data on the Number of Persons Delivered by Authorities of the MIA to the Dermatological-Venereal Institutions of the LSSR, 5 March 1971.

54 LNA LVA, 1854-1a-5, 1-11; here: 2. Information of the Riga City Prosecutor's Office to the LSSR Prosecutor, 31 December 1969. 
with immoral lifestyle. It seems, the draft order could have been elaborated with an aim to inform society, because the resolutions of the CM and instructions were confidential, whereas the PSS orders were made public. The Head of the LAC pointed that the concept of immoral lifestyle in the context of the VDs fighting only addressed "sexual debauchery" (I have not succeeded in finding the definition of sexual debauchery in normative acts). ${ }^{55}$ The document prepared by him indicates that the $\mathrm{HC}$ authorities wanted to establish a special medical labour re-educational institution (lechebno trudovoi profilaktorii) for coercive treatment of VDs infected people. The key idea was to isolate certain citizen groups from the rest of the society. However, it turned out that such institutions could be established under the supervision of the MIA, as opposed to the MHC. ${ }^{56}$ Therefore, after a few years in 1971 the MHC suggested to organize in the MIA system a medical labour re-educational institution for those, who have contracted VDs infections and who lead immoral-parasitic lifestyle. ${ }^{57}$

At the same time, the medical authorities started to use the concept "clandestine prostitution". It was argued that the prostitutes operating secretly could not be held criminally liable, because Article 112 of the Criminal Code intended punishment for deliberate infecting with VDs. Therefore, the MHC asked to issue an order about the coercive treatment of the respective category citizens (VDs infected people with immoral-parasitic lifestyle) and labour re-education in the medical labour re-educational institutions of the MIA for the time period that is not less than 6 months, namely, up to the moment, when the ones infected with gonorrhoea were removed from the registration (uchet) and when the ones infected with syphilis had completed one or two treatment courses. ${ }^{58}$ According to the MHC, only social isolation will prevent this citizen category from infecting other people. The existing regime in-patient hospitals attached to the dispensaries did not provide this, because after

55 LNA LVA, 938-6-430, 11. The Letter of the Department of Criminal Law, Criminal Procedure and Forensic Science, Faculty of Economics and Law at the State University of Latvia to the LAC at the CM of the LSSR, 18 April 1966; Ibid., 12-15; here: 13. Conclusion of the LAC at the CM of the LSSR on the Draft Decree of the PSS of the LSSR, 7 April 1966.

56 LNA LVA, 938-6-430, 14.

57 LNA LVA, 1022-7-456, 23, 24.

58 Ibid., 22. 
2-3 weeks' treatment the patients were discharged, in order to continue ambulatory treatment, however the patients of the respective category had not done it. Whereas in 1971 the PSS of the LSSR issued an Order "On the Amendments and Additions to Article 112 in the Criminal Code of the LSSR", which included liability for infecting somebody with VDs or for malicious avoidance of VDs treatment. ${ }^{59}$

Responding to the Decree of the PSS of the SU issued in 1971, ${ }^{60}$ the new instruction was approved, where the MIA and MHC added the fifth group to the existing four - individuals, who had contracted VDs and who avoided the control of medical examination. Also, two existing groups were specified. It was stated that sexual intercourses with the goal of material benefit was to be defined as prostitution, and the individuals who "lead disorderly sexual life" were gendered as "frivolous women" 61 thus releasing "frivolous" men from the intervention of medical authorities in their private lives only because of their gender. Overall, the 1971 instruction drew attention to selling of sex (formally justifying purchasing of sex), but the practice of another type of "disorderly sexual life" was referred only to women.

Both the ministries of $\mathrm{HC}$ and IA planned to improve VDs eradication, introducing new instruments for the mechanism of surveillance. In 1971, the MIA had a plan to keep a photo album of "frivolous women", male homosexuals and occupants of dens in law enforcement authorities of the municipal and regional districts, "in order to ensure operative identification of the sources of infection of VDs". ${ }^{62}$ The MIA anticipated that the MHC should use the latest scientific discoveries in the medical examinations of male homosexuals. ${ }^{63}$

59 LNA LVA, 1022-7-456, 65-69; here: 66. The Letter to the Head of the Central Administration of Medical and Preventive Care (lechebno-profilakticheskoi pomoshchi) of the MHC of the SU, 14 October 1971.

${ }^{60}$ LNA LVA, 938-6-971, 9. The Order of the Ministers of IA and HC of the LSSR, November 1971.

${ }^{61}$ LNA LVA, 938-6-971, 5-6. Draft Instruction of Ministries of HC and IA On the Application of the Resolutions of the CM of the LSSR No. 304, 26 May 1964 "On Measures to Fight VDs" and No. 301-312, 16 June 1971 "On Measures to Intensify the VDs Fight", November 1971."

62 LNA LVA, 270-3-4594, 136.

${ }^{63}$ Ibid., 137. 
Meanwhile, the MHC recommended introducing weekly raids according to the Leningrad pattern to deliver the suspects in male homosexuality for medical examination. ${ }^{64}$

\section{The Special Regime In-patient Hospital: Social Isolation}

From 1969 up to 1973 in the LSSR the morbidity rate of both, syphilis and gonorrhoea had increased each year. ${ }^{65}$ The 1973 resolution of the CM of the LSSR does not mention any specific groups. ${ }^{66}$ However, the 1973 complex VDs fighting plan prepared by the Ministries of IA and HC that supplemented the resolution mentions 7 subgroups in the first paragraph under a group defined as persons with an immoral and parasitic lifestyle alcoholics, idlers (tuneiadtsy), male homosexuals, "frivolous women", pimps, occupants of dens, as well as disseminators of VDs as a separate subgroup. ${ }^{67}$ Separation of disseminators of VDs seemingly indicates that the rest of the six groups are not disseminators of VDs, but as populations, who favour "sexual debauchery", "disorderly sexual life", deserve to be forcefully undressed against their will and subjected to medical manipulations.

In 1973 Latvia took the first place in the SU in terms of the syphilis morbidity. ${ }^{68}$ As a result, two new medical institutions for the treatment of VDs were founded. The republican dispensary that was closed down in 1956, was re-opened again. Its ambulatory care and in-patient hospital

64 LNA LVA, 270-3-4939, 148. Proposals of the MHC of the LSSR for a More Successful Fight of VDs, 23.12.1971.

65 The morbidity rate of syphilis / gonorrhoea per 100000 inhabitants in $1969-6.5$ / 156.9 , in $1970-10.4 / 149.2$, in $1971-28.8$ / 139 , in $1972-54.2 / 160$, in $1973-$ 82 / 170.4. See: LNA LVA, 270-3-5882, 165-172; here: 166. Report on the Situation Regarding the VDs Morbidity and Measures to Fight Them in the LSSR in 1973, 22 March 1974.

66 LNA LVA, 270-1c-2168, 9-12. The Resolution of the CM of the LSSR No. 219-5, 18 May 1973 "On Strengthening the Fight against VDs in the Republic. Classified".

67 LNA-LVA, 270-1c-2168, 13-16; here: 13. The Plan of Measures to Strengthen the Fight against VDs in the LSSR. Classified, 16 May 1973.

68 In 1973 the morbidity rate of gonorrhoea was 4183 persons or 170,4 per 100000 inhabitants. The morbidity rate of syphilis was 2014 persons or 82 per 100000 inhabitants. See: LNA LVA, 270-3-5882, 166. 
with two departments of venereal diseases and dermatological diseases for men and women were located in the former hospital of tuberculosis in Pērnavas Street, Riga. ${ }^{69}$ Whereas the recommendations provided by medical authorities in 1966 and 1971 regarding the establishment of medical-labour re-educational institution were implemented in 1973 in a different form. In Riga, on Maskavas Street 241 a venereological hospital of the City of Riga was founded. It was an institution, which implemented a special regime for the forced treatment and control of the people who had contracted VDs. Physician Dzidra Branta writes that it was intended for "socially un-adapted individuals - without a declared address (vagabonds), prostitutes (gradually the term was applied), patients, who refused the treatment, etc."70 The territory of the hospital was marked off by a stonewall, provided with internal and external signalisation system, as well as spotlights for the illumination of the territory. A special regulation was applied to the order to be followed at the hospital. ${ }^{71}$ Regiment of militsiya of the Administration of IA of the Riga EC provided 24/7 security - 28 militsiya men were on duty in 4 militsiya posts. Additionally, 4 officers of criminal investigation were in charge of the re-education of those persons, who maliciously avoided the VDs treatment or medical control. In 1979, for gross violation of the hospital regime in other dispensaries and medical prevention institutions 1074 patients were delivered to the special regime hospital in Riga. ${ }^{72}$

69 Dzidra Branta. Atmingas un apcere, 126.

70 Ibid., 127.

71 "Regulations on Closed-Type (rezhim zakrytogo tipa) Venereal Hospital for Compulsory Medical Treatment and Examination of VDs Infected Persons" were approved by the Ministries of IA and HC of the LSSR, 19 January 1973. See: LNA LVA, 1022-7-503, 19-26; here: 23. 24. Information on the Progress in the Execution of the Order of the MHC of the SU No. 320DSP, 12 April 1974, "On Measures to Further Strengthen the Fight against the Spread of VDs" in 1979, 12 February 1980.

72 Ibid. 


\section{Focus Extension: Towards Promiscuous Behaviour Generally}

After the 1974 resolution of the CM of the SU the CM of the LSSR demanded the MHC to be more proactive in finding individuals who had contracted VDs to ensure their medical treatment. ${ }^{73}$ While discussing the 1974 republican draft resolution, the MIA of the LSSR objected that people with "immoral and parasitic lifestyle" have to be viewed as a main source of the VDs, because a study carried out together with the MHC proved the otherwise. ${ }^{74}$ The MIA tried to achieve a provision that by the mid-1960s was already a reality in Great Britain where "the increased incidence of VDs was seen in official circles as "primarily a reflection of sexual promiscuity in the population". ${ }^{75}$ The Minister of IA (1972-1978), Jānis Brolišs (1930-1985), defended the idea to dismiss the category of individuals with "an immoral and parasitic lifestyle" as a main source of VDs, even in the meeting at the CM in the early 1974 . He emphasised that the spread of VDs occurs not only due to casual sexual contacts.

"For example, $75 \%$ of all diagnosed patients who contracted syphilis were infected not from casual sexual encounters but wives were infected by husbands, husbands - by wives, 32 individuals contracted infection from acquaintances and 32 individuals refused to give names of the persons from whom they contracted the disease."76

The Minister of IA Jānis Brolišs argued that law enforcement authorities fail to fight VDs, because there was no such law that would hold a detained person liable for providing information regarding the individual,

73 LNA LVA, 270-3-5837, 59-63. The Resolution of the CM of the LSSR No. 193, 9 April 1974 "On Progress of the Resolution of the CM of the LSSR No. 219-5, 18 May 1973 "On Strengthening the Fight against VDs in the Republic. Classified".

74 LNA LVA, 270-3-5882, 157-159; here: 157-158. Reference on the Draft Resolution of the CM of the LSSR "On Progress of the Resolution of the CM of the LSSR No. 219-5, 18 May 1973 "On Strengthening the Fight against VDs in the Republic"”, 25 March 1974.

75 David Evans, "Sexually Transmitted Disease Policy in the English National Health Service, 1948-2000”, 246.

76 LNA LVA, 270-3-5882, 188-200; here:188. The Meeting at the CM of the LSSR on the Draft Resolution of the CM of the LSSR "On Progress of the Resolution of the CM of the LSSR No. 219-5, 18 May 1973 "On Strengthening the Fight against VDs in the Republic"', March 1974. 
who was the source of infection. The Deputy Head of the CM (1967-1985) Viktors Krūmiňš even recommended to extend the places, where the catching campaigns of citizens should be implemented.

"We need to make the next step now and we should include the housing management institutions, all hotels, the most evil public catering places. All these individuals are known. The comrade, who is engaged in this, said that the waiters and bartenders know all these hustlers and easy life hunters by names. It is also necessary to discuss this subject very seriously with the individuals, who are responsible for these issues in the public catering field." 77

Finally, it was stated that exactly category of people with an immoral and parasitic lifestyle "have always been and still are the main distributors of VDs regardless of whether their number has decreased and regardless of the fact that along with the increased incidence of VDs other paths (encounters) appear that spread venereal diseases as it is currently happening". ${ }^{78}$ Brolišs, the minister of IA, for his part, considered that focusing on individuals with "an immoral and parasitic lifestyle" alone could not solve the problem of VDs in the republic. The idea of extending the range of people subject to medical control was already expressed at the meeting of the MHC council. At the meeting of the MHC council on 20 September 1973 the Liepāja dermatological and venereal disease specialist suggested to extend the range of people to be subjected to medical control, "wassermanning" all the individuals, who were isolated in the medical sobering stations, namely, to carry out the syphilis diagnostic tests - the blood test, by testing Wassermann reaction. Already in the letter on April 1973 Nikolajevskis had suggested it to the Chief of the Liepāja medical sobering station. The Chief of the sobering station even offered to examine absolutely all the people, who were detained by the Department of Interior of the Executive Committee of the Liepāja People's Council of Deputies, that is, around seven thousand individuals. ${ }^{79}$ However, even the Deputy Minister of the Ministry of Interior (1969-1984) Anrijs Kavalieris (1933-2016) saw the idea as too drastic, saying that "as regards the question of "wassermanization' of $100 \%$ individuals taken to the sobering station, I am not ready

77 LNA LVA, 270-3-5882, 199.

78 Ibid., 158.

${ }^{79}$ LNA LVA, 1022-4-235, 424. 
to answer, whether it would be legally and politically correct." 80 All in all, he concluded that with "our contingents", that is, marginalised populations supervised by the law enforcement authorities, "we will not solve this problem in the republic". ${ }^{81}$

From 1980 on at the latest, no categorized citizens were mentioned in the VDs fighting plans (the plans for 1974-1979 have not been found), although the medical and militsiya control over the groups mentioned in the 1973 plan was continued. Nevertheless, the central explanatory concepts informing medical and media discourses over the prophylaxis of VDs were to become 'sexual promiscuity' and 'permissiveness'.

Thus, the authorities extended the range of the categorised citizens referring compulsory medical control including sexual health to the various groups of the so-called rank-and-file citizens. Regular health checks were compulsory for the employees working in the food and public catering industries. Physicians recorded their health condition in a special document called the sanitary booklet (sanitarnaia knizhka). In the early 1970s the venereal health had to be checked after every 3 months. In 1973 the CM of the LSSR elaborated a draft resolution, stipulating that further on the health checks must be carried out once a month. ${ }^{82}$ The CM grounded the necessity for such changes on the statistics of the incidence of VDs. In 1973, syphilis morbidity in comparison with 1972 had increased for 2.5 times. The analysis of the employment data of the infected individuals provided evidence that $8.5 \%$ worked in the respective industries. Morbidity among students in the higher education establishments and comprehensive schools was considered as high. ${ }^{83}$

In 1973, to promote VDs prevention and provide sexual education to young people, the CM of the LSSR asked to attract mass information channels - the television of Latvia, radio, republican periodicals. In 1973, all together 12 radio conversations took place and 9 articles on

80 LNA LVA, 1022-4-235, 436.

81 Ibid., 435.

82 LNA-LVA, 270-3-5882, 187. The Draft Resolution of the CM of the LSSR on Changing the Term for Medical Examination of Persons Employed in the Food Industry, 14 May 1973.

83 LNA-LVA, 270-3-5882, 174-177; here: 175. The Draft Resolution of the CM of the LSSR "On the Progress of the Resolution of the CM of the LSSR No. 219-5, 18 May 1973 "On Strengthening the Fight against VDs in the Republic"”, prepared by the MHC of the LSSR, 20 March 1974. 
these topics were published in the republican newspapers and 5 articles in magazines. ${ }^{84}$ Two public addresses were held on the television of Latvia, after which the management of the television of radio broadcasting forbade the MHC to present public speeches on the television. The Deputy Minister of the LSSR MHC Gunārs Orleāns ${ }^{85}$ argued that, taking into account the popularity of television, the broadcast shows on the VDs prevention must be brought back, because morbidity in rural areas increased. Medical authorities demanded that the CM of the LSSR Committee of Television and Radio Broadcasting would comply unconditionally (neuklonnogo vypolneniia) to the request to demonstrate popular science films and physician-specialist conversations each month on the television. ${ }^{86}$

In the meeting at the CM in the early 1974 the Deputy Head of the State Television and Radio Broadcasting Committee (1972-1986) Jāzeps Barkāns had to explain the Committee's refusal to broadcast television records on the topic of VDs prevention. He said:

"It must be noted that we watched the films, which were recorded for broadcasting on television. And it must be noted that these are not [suitable] for the screen, taking into account the audiences that watch them, namely, women and children. We have to find other films, perhaps we should invite physicians to television and discuss other medical questions."

The Head of the CM (1970-1988) Jurijs Rubenis pointed out that the language that is used to talk about the VDs prevention should be direct, so that the audiences could understand it. He provided his arguments in the following way:

"We are not telling you, comrade Barkāns, what and how you should be doing. We want that the television would be actively engaged in this work. But what kind of forms and methods - whether it would be a film or staged drama, play or tragedy - these are your rights, that's to be decided by you. But our duty - to remind you once again that you have to do a big job in the prevention of these diseases. [..]

84 LNA-LVA, 270-3-5882, 171-172.

85 Gunārs Orleāns (1931-1989), Chief physician of Preili Hospital (1956-1963), the deputy of the Administration of medical and preventive care of the MHC of the LSSR (1963-1969), the deputy of the minister of HC of the LSSR (1969-1989).

86 LNA-LVA, 270-3-5882, 177. 
But so far you have not focused on this job, and it is necessary to speak [about it] not on the side note or cautiously, but so that one can understand what you are talking about. And you have to do it. If this film is not suitable - don't show it, make another one, that is your business." 87

Consequently, in the early 1970s, the VDs prevention discourse was invented in mass media in Soviet Latvia. The VDs fighting measures were activated once again in 1977. The resolution of CM of the SU stipulated that additional measures fighting VDs must be taken and the efficiency of the interdepartmental commissions must be increased. In a month the resolution of the CM of the LSSR was issued. ${ }^{88}$ In 1980, the MHC of the LSSR stated that in terms of the practice of VDs fighting the "system of formal contacts" that has been worked out by experience of the collaboration between the authorities of health care, internal affairs and prosecution, was operating successfully. ${ }^{89}$

The 1985 Order (prikaz) of the MIA of the SU, terminated the operative militsiya group at the Criminal Investigation Department of the Administration of IA of the Riga EC for fighting VDs which had been working since 1965 by the May $1985 .{ }^{90}$ Still, there are no facts to argue that the Decree had something to do with Gorbachev's reform policies. The MIA of the LSSR obeyed the order, but made a suggestion to the CC of the CPL to get it cancelled. Further on, the VDs fighting policy disappeared from the agenda of authorities. At the end of 1986, the joint ad hoc committee which had been established to fight VDs in Riga also ceased its work. In 1987, the prostitution was legalized in the LSSR.

87 LNA-LVA, 270-3-5882, 199-200.

88 LNA LVA 938-6-1572, 64-65. The Resolution of the CM of the SU No. 372, 12 May 1977 "On Additional Measures to Strengthen the Fight against the Spread of VDs"; LNA LVA, 938-6-1572, 42-45. The Resolution of the CM of the LSSR No. 400, 29 June 1977 "On Additional Measures to Strengthen the Fight against the Spread of VDs".

89 LNA-LVA, PA-101-59-200, 19-20; here: 19. Proposals for the Prevention and Strengthening the Fight against Prostitution in the LSSR, 30 December 1986.

90 Ibid. 


\section{Conclusions}

The ideological perspective of the SU claiming that the victory of the Soviet ideology and lifestyle are a guarantee for the elimination of VDs in the socialist society caused continuous tension for the $\mathrm{HC}$ authorities. In the early 1960s the medical authorities of the LSSR proposed to the CM of the LSSR that the law enforcement authorities have a responsibility to engage in the VDs fighting together with medical personnel. In this way, the medical knowledge/treatment of VDs intersected with the issues of social control, focusing on social groups that Soviet authorities had turned into marginalised populations, which were easy to subdue with the help of various legislative acts: alcoholics, idlers (tuneiadtsy), homosexuals, "frivolous women", pimps, occupants of dens, as well as disseminators of VDs. Such a stance had huge inertia - despite the attempts of the MIA to get rid of the central thesis of anti-VDs policy that stated individuals with immoral and parasitic lifestyle as a main source of contracting VDs, the minister of IA failed to achieve it in 1974.

The Soviet VDs fighting policy marginalised certain Soviet citizen groups, which were also viewed as supposedly promiscuous, using repressive methods of control, according to the ideological settings about the VDs as the remnants of capitalism in the people's minds. This was manifested in the institutional system: legislation, decisions and instructions, the organisation of health care system and the involvement of law enforcement authorities in fighting VDs.

\section{Padomju pilsoṇu kategorizēšana venerisko slimību apkarošanas politikas kontekstā padomju Latvijā no Hruščova līdz Gorbačova valdīšanas laikam (1955-1985)}

Padomju vara saslimstību ar veneriskajām slimībām ideologiski interpretēja kā trūkumu, kas piemīt kapitālistiskajām valstīm un kas visdrīzākajā laikā tiks likvidēts Padomju Savienībā.

Neatkarīgajā Latvijas Republikā (1918-1940) 20. gadsimta 30. gados ik gadu tika reǵistrēti apmēram 10 tūkstoši ar veneriskajām slimībām inficēto, turpretī padomju Latvijā, neraugoties uz intensīvo migrāciju no citām 
Padomju Savienības republikām, 1959. gadā tika reǵistrēts apmēram viens tūkstotis ar veneriskajām slimībām inficētu padomju pilsoņu, turklāt visaugstākais rādītājs bija 1973. gadā - ap sešiem tūkstošiem inficēto.

Tādā vēsturiskajā kontekstā padomju varas aktivitātes venerisko slimību apkarošanā raksturo savdabīga ideoloǵiska apsēstība. Lai sasniegtu mērksi kḷūt par valsti, kurā likvidētas veneriskās slimības, Padomju Savienība praktizēja drastisku dispanserizācijas sistēmu šo slimību ārstēšanā, kurai galvenokārt pakḷāva dažas iedzīvotāju kategorijas. Šīs marginalizēto iedzīvotāju grupas tika identificētas venerisko slimību apkarošanas prakses iekšējās lietošanas dokumentos, kamēr padomju valdības lēmumi, ko pārsvarā marķēja spiedogs "nav publicējams", formāli atbilda dzimumlīdztiesības un padomju tiesiskuma idejām. Varas institūcijas uzskatīja, ka tās drīkst aizvainot marginalizēto iedzīvotāju grupas pārstāvjus, piespiedu kārtā pakḷaujot tos nepamatotai medicīniskajai apskatei, tādējādi atļaujoties ignorēt padomju tiesiskumu.

Vienlaikus, vērtējot tādas prakses attiecināšanu uz plašākām iedzīvotāju masām, tika atzīts, ka tas neveicinās padomju tiesiskuma nostiprināšanu. Raksta mērķis ir atklāt iedzīvotāju kategorizēšanas prakses attīstību saistībā ar venerisko slimību apkarošanas politiku Latvijas Padomju Sociālistiskajā Republikā (Latvijas PSR).

Lai analizētu, kā padomju pilsoņi tika kategorizēti, realizējot venerisko slimību apkarošanas politiku padomju Latvijā laika posmā no 1955. līdz 1985. gadam, vispirms raksturota dispanserizācijas sistēma, ko šo slimību apkarošanai pēc Otrā pasaules kara Latvijā ieviesa padomju okupācijas vara atbilstoši praksei, kas jau pastāvēja Padomju Savienībā, pēc tam izpētīts, kā 50. gados venerisko slimību apkarošanas prakses sekundārā līmeņa dokumentos tika ieviestas īpašas riska grupas - personas ar antisociālu parazītisku dzīvesveidu, homoseksuāḷi un prostitūtas - un kā mērksgrupu saraksts tika detalizēts un papildināts.

Analizējot nozīmīgākos venerisko slimību apkarošanas prakses dokumentus - 1964. gada un 1971. gada instrukcijas -, noskaidrots, kā starpresoru diskusiju rezultātā venerisko slimību apkarošanas prakse no dzimumneitrālas kḷuva par dzimtes (sieviešu) specifisku. Kā prakse tā tika institucionalizēta, izveidojot īpašu operatīvo milicijas grupu un uzturot prostitūtu, homoseksuāḷu un "izvirtības perēkḷu” turētāju (kā šķietami venerisko slimību inficēto personu) reǵistrācijas kartotēku vienlaikus medicīniskajās un sabiedrisko kārtību sargājošajās varas institūcijās. 
Atslēgvārdi: venerisko slimību apkarošana, amorāls un parazītisks dzīvesveids, marginalizētas iedzīvotāju grupas, prostitūcija, homoseksuāļi, Padomju Savienība, Latvijas PSR.

\section{Secinājumi}

Raksturojot venerisko slimību apkarošanas prakses attīstību 70. un 80. gados, argumentēts, ka šajā periodā fokuss tika sašaurināts uz personām ar amorāli parazītisku dzīvesveidu, jo 1973. gadā tika izveidota speciālā režīma slimnīca tieši minētās mērķgrupas septiņu apakšgrupu (alkoholiķu, oficiālā valsts darbā nestrādājošo (no krievu val. тунеядиьы (tuneiadtsy) - liekēži), homoseksuāḷu (vīriešu), "vieglas uzvedības sieviešu", savedēju, izvirtības perēkḷu iemītnieku, kā arī venerisko slimību izplatītāju) piespiedu ārstēšanai. Vienlaikus sabiedrisko kārtību sargājošās varas institūcijas centās paplašināt kontrolējamo iedzīvotāju loku, lai preventīvi novērstu uz gadījuma sakariem orientētu seksuālo uzvedību visplašākajās iedzīvotāju masās, tāpēc tika veikta venerisko slimību profilakse, popularizētas seksuālās zināšanas ne tikai preses publikācijās kopš 60 . gadiem, bet no 70. gadiem - arī radio un TV diskursā.

Padomju Savienības ideolog̣iskās nostādnes par to, ka Padomju Savienības Komunistiskās partijas kongresu lēmumi ir garantija tam, ka sociālistiskajā sabiedrībā veneriskās slimības tiks likvidētas, radīja pastāvīgu spriedzi veselības aizsardzības varas institūcijās. Sešdesmito gadu sākumā Latvijas PSR Veselības aizsardzības ministrija ierosināja Latvijas PSR Ministru Padomei uzlikt sabiedrisko kārtību sargājošajām varas institūcijām par pienākumu iesaistīties venerisko slimību apkarošanā. Tādā veidā medicīniskās zināšanas / venerisko slimību ārstēšana krustojās ar iedzīvotāju sociālās kontroles mērķiem, kas l̦āva koncentrēties uz iepriekš minētajām sociālajām grupām, ko padomju varas institūcijas ar dažādu likumdošanas aktu palīdzību bija padarījušas par viegli diskriminējamām.

Tādai nostājai bija milzīga inerce - neraugoties uz Latvijas PSR Iekšlietu ministrijas mēǵinājumu 1974. gadā paplašināt venerisko slimību apkarošanas politiku, attiecinot to arī uz tā sauktajiem ierindas iedzīvotājiem, nozares ministram to neizdevās panākt. Tādējādi periodā līdz 1985. gadam padomju Latvijas venerisko slimību apkarošanas politika marginalizēja specifiskas padomju pilsoņu sociālās grupas, kuras uzskatīja par potenciāli 
izlaidīgām seksuālās uzvedības ziṇā. Venerisko slimību apkarošana notika, izmantojot represīvas kontroles metodes atbilstoši padomju ideologiskajai tēzei par veneriskajām slimībām kā kapitālisma paliekām cilvēku prātos. Tas izpaudās institucionālajā sistēmā - likumdošanā, lēmumos un instrukcijās, veselības aizsardzības sistēmas organizācijā un sabiedrisko kārtību sargājošo varas institūciju iesaistē šo slimību apkarošanā.

\section{Ineta Lipša}

Dr. hist., Latvijas Universitātes Latvijas vēstures institūts / Institute of Latvian History at University of Latvia 